Jurnal Cendekia Akuntansi

Volume 2, Nomor 2

pISSN 2723-0104

Kediri, Desember 2021

\title{
PENGARUH TINGKAT KESULITAN KEUANGAN DAN TINGKAT HUTANG TERHADAP KONSERVATISME AKUNTANSI PADA PERUSAHAAN FOOD \& BEVERAGE
}

\author{
Oleh: \\ Miladiah Kusumaningarti \\ Dosen Akuntansi Universitas Islam Kadiri, Kediri \\ Email : nimilakusuma@gmail.com
}

\begin{abstract}
This study was conducted to determine the partial and simultaneous effect of the Level of Financial Difficulty and the Level of Debt on Accounting Conservatism in Food \& Beverage Companies listed on the Indonesia Stock Exchange for the period 2018-2020.The population used is 23 Food \& Beverage Companies listed on the Indonesia Stock Exchange. The sampling technique used is purposive sampling and found 12 samples of companies with financial data for 3 years. The analysis technique used is the Classical Assumption Test and Multiple Linear Regression Test with the help of SPSS 21. The results showed that partially The level of Financial Difficulty has a positive and significant influence on Accounting Conservatism in Food \& Beverage Companies in 2018-2020. Partially, the Debt Level has a positive and significant influence on Accounting Conservatism in Food \& Beverage Companies in 2018-2020. And simultaneously the Levelof Financial Difficulty and the Level of Debt have a significant influence on Accounting Conservatism in Food \& Beverage Companies in 2018-2020.
\end{abstract}

Keywords : Financial Distress, Leverage and Accounting Conservatism

\begin{abstract}
Abstrak
Penelitian ini dilakukan untuk mengetahui pengaruh secara parsial dan simultan antara Tingkat Kesulitan Keuangan dan Tingkat Hutang terhadap Konservatisme Akuntansi pada Perusahaan Food \& Beverage yang terdaftar di BEI periode 2018-2020. Populasi yang digunakan adalah 23 Perusahaan Food \& Beverage yang terdaftar di Bursa Efek Indonesia. Teknik pengambilan sampel yang digunakan yaitu purposive sampling dan ditemukan 12 sampel perusahaan dengan data keuangan selama 3 tahun. Teknik analisis yang digunakan adalah Uji Asumsi Klasik dan Uji Regresi Linier Berganda dengan bantuan SPSS 21. Hasil penelitian menunjukkan bahwa secara parsial Tingkat Kesulitan Keuangan memiliki pengaruh positif dan signifikan terhadap Konservatisme Akuntansi pada Perusahaan Food \& Beverage Tahun 2018-2020. Secara parsial Tingkat Hutang memiliki pengaruh positif dan signifikan terhadap Konservatisme Akuntansi pada Perusahaan Food \& Beverage Tahun
\end{abstract}


2018-2020. Dan secara simultan Tingkat Kesulitan Keuangan dan Tingkat Hutang memiliki pengaruh signifikan terhadap Konservatisme Akuntansi pada Perusahaan Food \& Beverage Tahun 2018-2020.

Kata kunci : Financial Distress, Leverage dan Konservatisme Akuntansi

\section{Pendahuluan}

Laporan keuangan merupakan laporan yang menggambarkan kondisi keuangan sebuah perusahaan pada periode tertentu. Menurut Margaretha dan Ramadhan (dalam Ramadhani dan Sulistyowati, 2019:79), bahwa "Laporan keuangan pada dasarnya merupakan alat yang dibutuhkan oleh pihak internal maupun eksternal di dalam memperoleh informasi mengenai posisi keuangan perusahaan tersebut."

Standar Akuntansi Keuangan telah memberikan kebebasan dalam menentukan metode atau model akuntansi yang akan digunakan untuk menyusun laporan keuangan perusahaannya. Kebebasan dalam memilih metode dapat dimanfaatkan oleh tiap perusahaan mendapatkan hasil laporan keuangan yang beragam atau berbeda-beda. Karena kinerja perusahaan memiliki ruang lingkup yang tidak pasti, maka dalam hal ini prinsip konservatisme menjadi salah satu pertimbangan oleh perusahaandalam akuntansi dan laporan keuangannya.

Menurut Watts (dalamRamadhani dan Sulistyowati, 2019:79), mendefinisikan konservatisme "sebagai prinsip kehati-hatian dalam pelaporan keuangan dimana perusahaan tidak terburu-buru dalam mengakui, mengukur aktiva dan laba serta segera mengakui kerugian dan hutang yang mempunyai kemungkinan yang terjadi." Konservatisme adalah prinsip akuntansi yang ketika diterapkan oleh perusahaan akan menghasilkan pendapatan serta aset yang cenderung rendah, sedangkan biaya disini cenderung tinggi.

Faktor yang dapat mempengaruhi prinsip konservatisme ini salah satunya ialah financial distress atau kesulitan keuangan. Menurut Suprihastini dan Pusparini (dalam Ramadhani dan Sulistyowati, 2019:81), 'jika perusahaan mengalami tingkat kesulitan keuangan yang tinggi maka manajer akan cenderung mengurangi tingkat konservatisme akuntansinya.' Kesulitan keuangan diawali dengan ketidakmampuan perusahaan dalam memenuhi pembayaran kewajibannya yang akan jatuh tempo. Kondisi keuangan yang bermasalah dapat membuat pihak manajemen untuk mengatur tingkat konservatisme akuntansinya.

Faktor lain yang dianggap dapatmempengaruhi konservatismeakuntansi ialah tingkat hutang perusahaan. Rasio hutang ini dapat menunjukkan besarnya hutang ataumodal yang membiayai aktiva atau asetsebuah perusahaan. Tingkat hutangatau leverage memiliki arti bahwa semakin tinggi nilai tingkat hutang, maka semakin tinggi ketidakkemampuan perusahaan dalam melunasi kewajibannya. Sehingga 
perusahaan akan berusaha melaporkan laba yang sekarang dimana laba yang lebih tinggi dengan mengurangi biaya- biaya yang ada.

Oleh karena itu, tujuan dari penelitian ini adalah untuk mengetahuipengaruh secara parsial dan simultan tingkat kesulitan keuangan dan tingkat hutang terhadap konservatisme akuntansi pada perusahaan food \& beverage yang terdaftar di BEI periode2018-2020. Berdasarkan penjabaran dari latar belakang di atas, maka peneliti tertarik untuk melakukan penelitian yang berjudul "Pengaruh Tingkat Kesulitan Keuangan dan Tingkat HutangTerhadap Konservatisme Akuntansi pada Perusahaan Food \& Beverage di BEI Periode 2018-2020"

\section{Tinjauan Pustaka}

\section{Kesulitan Keuangan}

Kesulitan keuangan atau biasa dikenal dengan financial distress adalah ketidakmampuan sebuah perusahaan dalam melunasi kewajibannya atau hutang jangka pendeknya ketika sudah memasuki jatuh tempo. Menurut Hanafi dan Halim (2016:276), "Kesulitan keuangan bisa digambarkan di antara dua titik ekstream yaitu kesulitan likuiditas jangka pendek (yang paling ringan) sampai insolvabel (yang palingparah)." Kesulitan keuangan jangka pendek biasanya bersifat sementara, tetapi bisa berkembang menjadi parah. Kesulitan keuangan dapat terjadi karena perusahaan tidak mampu mengelola dan menjaga kestabilan atas kinerja keuangannya. Dampak dari kesulitan ini dapat menyebabkan hilangnya potensi pendapatan operasional perusahaan yang kemungkinan akan menyebabkan perusahaan tersebut mengalami kerugian operasional dan kerugian bersih. Kondisi seperti inilah yang menyebabkan perusahaan mengalami financial distress atau disebut dengan kesulitan keuangan (Wijoyo,2016:456).

\section{Hutang}

Menurut Munawir (2010:18), menyatakan bahwa pengertian dari hutang adalah "total dari seluruh kewajiban keuangan perusahaan kepada kreditur yang statusnya belum terpenuhi, dimana hutang disinimerupakan modal atau sumber dana perusahaan." Menurut Hantono (2018:16), menyatakan bahwa "hutang merupakan total dari seluruh kewajiban yang dimiliki perusahaan karena telah melakukan pinjaman atau membeli barang dengan kredit, yang dimana sifatnya harus segera dilunasi." Dari pengertian diatas dapat disimpulkan bahwa hutang merupakan kewajiban perusahaan yang timbul akibat aktivitas-aktivitas perusahaan yangharus segera dibayarkan oleh perusahaan.

\section{Konservatisme Akuntansi}

Menurut Financial Accounting Standard Boad (dalam Alhayati, 2013:04), menyatakan bahwa konservatisme akuntansi adalah 'reaksihati-hatisaat menghadapi ketidakpastian perusahaan yang dimana sebelumnya sudah dengan pertimbangan.' 
Menurut Watts (dalam Putri, 2018:17), mengemukakan konservatisme akuntansi adalah 'sebuah prinsip kehati-hatian perusahaan dalam melaporkan kondisi keuangannya dengan tidak terburu- buru, mulai dari mengukur aset dan laba dan mengakui atas kerugian atau hutang yang mungkin sedang dialami.' Konservatisme akuntansi merupakan sebuah implikasi atas prinsip akuntansiyang mengakui adanya kerugian atau biaya yang akan terjadi, dan disini perusahaan tidak segera mengakui penghasilannya yang mungkin akan terjadi.

\section{Teori Hubungan Antar Variabel}

\section{Kesulitan Keuangan Terhadap Konservatif Akuntansi}

Kesulitan keuangan merupakan sebuah sinyal awal atau gejala awal sebuah perusahaan sebelum mengalami kebangkrutan. Hal ini biasanya ditandai dengan adanya penurunan atas kondisi keuangan sebuah perusahaan. Kebangkrutan ini bisa terjadi karena perusahaan gagal menghasilkan laba dalam kegiatan operasionalnya, dan jugaperusahaan tidak mampu dalam melunasi hutang-hutangnya. Dan terjadinya kesulitan keuangan pada sebuah perusahaan dapat dijadikan motivasi para manajer untuk mengatur konservatif akuntansi atau tingkat kehati-hatian dalam akuntansinya (Setyaningsih, 2008).

H1 Tingkat Kesulitan Keuangan berpengaruh terhadap Konservatif Akuntansi

\section{Tingkat Hutang Terhadap Konservatif Akuntansi}

Hutang merupakan sebuah kewajiban yang harus diberikan atau dibayarkan kepada pihak yangbersangkutan atas transaksi yang terjadi pada masa lalu. Dana atas hutang yang digunakan perusahaan untuk membiayai kegiatan operasionalnya dapat berasal dari internal perusahaan dan eksternal perusahaan. Sehingga disini perusahaan harus menggunakan prinsip konservatif akuntansi atau kehati-hatian yang dimana dapat dijadikan landasan untuk menghasilkan laba. Oleh karena itu, dengan adanya tingkat hutang yang semakin tinggi maka permintaan atas penerapan prinsip konservatifakuntansi juga akan semakin tinggi,dimana pihak kreditur disini memiliki kepentingan untuk memastikan dana yang telahdiberikan dimanfaatkan dengan baik, serta dapat menghasilkan keuntungan bagi para kreditur (Alhayati, 2013).

H2 Tingkat Hutang berpengaruh terhadap Konservatif Akuntansi

\section{Kesulitan Keuangan dan Tingkat Hutang Terhadap Konservatif Akuntansi}

Terjadinya kesulitan keuangan pada sebuah perusahaan dapat dijadikan motivasi para manajer untuk mengatur konservatif akuntansi atau tingkat kehati-hatian dalam akuntansinya. Adanya tingkat hutang yang semakin tinggi maka permintaan atas penerapan prinsip konservatif akuntansi juga akan semakin tinggi, dimana pihak kreditur disini memiliki kepentingan untuk memastikan dana yang telah diberikan dimanfaatkan dengan baik, serta dapat menghasilkan keuntungan bagi para kreditur. 
H3 Tingkat Kesulitan Keuangan dan Tingkat Hutang berpengaruh terhadap Konservatif Akuntansi.

\section{Metode Penelitian}

\section{Jenis Penelitian}

Menurut Kasiram (dalam Sujarweni, 2015: 39) mengemukakan bahwa "penelitian kuantitatif adalah suatu proses menemukan pengetahuan yang menggunakan data berupa angka sebagai alat menganalisis keterangan mengenai apa yang ingin diketahui" Data yang digunakan dalam penelitian ini adalah laporan keuangan tahunan pada perusahaan food \& beverage yang terdaftar di BEI periode 2018-2020.

\section{Populasi dan Sampel}

Menurut Sugiyono (2013:117), "populasi adalah generalisasi yang terdiri atas objek ataupun subjek yang mempunyai kualitas dan karakteristik tertentu yang ditetapkan oleh peneliti untuk dipelajari dan ditarik kesimpulannya." Dalam penelitian ini populasi yang diambil adalah keseluruhan laporan keuanganperusahaan food \& beverage yangterdaftar di Bursa Efek Indonesia periode 2018-2020. Jumlah populasi yang ada adalah sebanyak 23 perusahaan food \& beverage.

Menurut Sugiyono (2013:118) "sampel adalah bagian dari jumlah dan karakteristik yang dimiliki oleh populasi tersebut." Sampel yang diambil dalam penelitian ini adalah hanya sebagian laporan keuangan perusahaan food \& beverage yang memenuhi kriteria yang telah ditentukan pada periode 2018-2020 yaitu berjumlah 12 perusahaan.

\section{Definisi Operasional Variabel}

1. Kesulitan Keuangan

$$
Z^{\prime} \text {-Score }=1,2 \mathrm{a}+1,4 \mathrm{~b}+3,3 \mathrm{c}+0,6 \mathrm{~d}+1,0 \mathrm{e}
$$

2. Tingkat Hutang

$$
\text { DER }=\frac{\text { Total Debt }}{\text { Total Equity }}
$$

3. Konservatisme Akuntansi

$$
N A M=\frac{\text { Harga Pasar per Saham }}{\text { Nilai Buku per Saham }}
$$

\section{Teknik Analisis Data}

Uji Asumsi Klasik

1) Uji Normalitas 
"Uji normalitas bertujuan untuk menguji apakah dalam model regresi, variabel independen danvariabel dependen memiliki distribusi normal atau tidak"(Ghozali, 2016:154).

2). Uji Multikolinieritas

Menurut Ghozali (2016:103) "uji multikolinieritas bertujuan untuk menguji apakah model regresi ditemukan adanya korelasi antarvariabel bebas (variableindependent)".

3). Uji Heteroskedastisitas

Menurut Ghozali (dalam Sujarweni,2015:226) 'uji heterokedastisitas adalah suatu keadaan dimana varians dan kesalahan penggangu tidak konstan untuk semua variabel bebas'.

4). Uji Autokorelasi

"Uji autokorelasi bertujuan menguji apakah dalam model regresi linier ada korelasi antar kesalahan pengganggu pada periode $t$ dengan kesalahan pengganggu pada periode sebelumnya" (Ghozali, 2016:107).

\section{Analisis Regresi Linier Berganda}

Menurut Ghozali (dalam Sujarweni, 2015:227), 'Analisis inibertujuan untuk mengetahui pengaruh atau hubungan secara linier antara dua atau lebih variable independen dengan skala pengukuran atau rasio'.

Rumus persamaan regresi adalah :

$$
\mathrm{Y}=\alpha+\beta 1 \mathrm{X} 1+\beta 2 \mathrm{X}_{2}+\mathrm{e}
$$

1). Uji t (Uji Parsial)

Menurut Ghozali (dalam Sujarweni, 2015:229), "uji statistik t digunakan untuk mengetahui seberapa jauh pengaruh satu variabel independen atau variabel penjelas secaraindividual dalam menerangkanvariabel dependen."

2). Uji f (Uji Simultan)

Menurut Sujarweni (2015:228), "Signifikansi model regresi secara simultan diuji dengan melihat nilai signifikansi (sig) di mana jika nilai sig dibawah 0,05 maka variabel independen akan berpengaruh terhadap variabel dependen."

\section{3). Uji Koefisien Determinasi $\left(\mathrm{R}^{2}\right)$}

Menurut Ghozali (dalam Sujarweni, 2015:228) mengemukakan bahwa "semakin tinggi nilai $\mathrm{R}^{2}$ maka semakin besar proporsi dari total variasi variabel dependen yang dapat dijelaskan oleh variabel independen". 


\section{Hasil Penelitian}

\section{Uji Normalitas}

Tabel 1. Uji Normalitas

\begin{tabular}{|l|c|}
\hline 1-Sample KS & U. Residual \\
\hline Asymp Sig (2-tailed) & 0,905 \\
\hline \multicolumn{2}{|c|}{ (Sumber : Data diolah 2021$)$}
\end{tabular}

(Sumber : Data diolah, 2021)

Nilai sig kolmogorov smirnov sebesar 0,905 artinya nilai sig tersebut lebih besar dari nilai probabilitas 0,05 . Maka dapat disimpulkan bahwa data dalam penelitian ini berdistribusi normal.

\section{Uji Multikolinearitas}

Tabel 2. Uji Multikolinearitas

\begin{tabular}{|l|l|l|}
\hline \multicolumn{1}{|c|}{ Variabel } & Tolerance & VIF \\
\hline $\begin{array}{l}\text { Kesulitan } \\
\text { Keuangan }\end{array}$ & 0,788 & 1,269 \\
\hline $\begin{array}{l}\text { Tingkat } \\
\text { Hutang }\end{array}$ & 0,788 & 1,269 \\
\hline
\end{tabular}

(Sumber : Data diolah, 2021)

Nilai tolerance variabel Kesulitan Keuangan dan variabel Tingkat Hutang lebih besar dari 0,1 dan didapatkan nilai VIF variabel Kesulitan Keuangan dan variabel Tingkat Hutang lebih kecil dari 10. Jadi dapat disimpulkan analisis model regresi variabel tidak terdapat gejala multikolinearitas.

\section{Uji Heteroskedastisitas}

\section{Gambar 1. Uji Heteroskedastisitas}

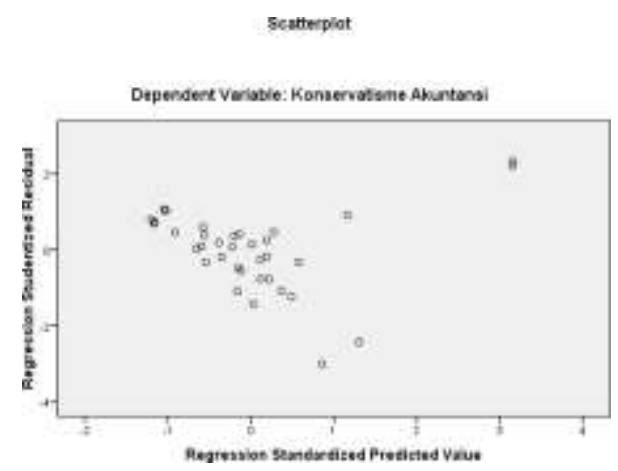

(Sumber : Data diolah, 2021)

Hasil uji heteroskedastisitaspada gambar scatterplot diatas bisa dilihat bahwa pola titik-titik menyebar dengan acak dan tidak beraturan, dan pola titik-titiknya 
berada diatas dan dibawah angka 0 pada sumbu Y. Maka dapat disimpulkan bahwa model regresipada penelitian ini terbebas dari gejala heteroskedastisitas.

\section{Uji Autokorelasi}

\section{Tabel 3. Uji Autokorelasi}

\begin{tabular}{|l|}
\hline Durbin-Watson \\
\hline 0,751 \\
\hline
\end{tabular}

(Sumber : Data diolah, 2021)

Diketahui nilai Durbin Watson sebesar 0,751 dan nilai ini diantara -2 dan +2 . Maka dapat disimpulkan bahwa pengujian dalam penelitian ini tidak terjadi gejala autokorelasi.

\section{Analisis Regresi Linier Berganda}

Tabel 4. Regresi Linier Berganda

\begin{tabular}{|l|l|}
\hline Variabel & Regresi \\
\hline Konstanta (a) & $-11,947$ \\
\hline Kesulitan Keuangan $\left(\mathrm{X}_{1}\right)$ & $-1,141$ \\
\hline Tingkat Hutang $\left(\mathrm{X}_{2}\right)$ & 11,358 \\
\hline
\end{tabular}

(Sumber : Data diolah, 2021)

$\mathrm{Y}=-11,947+1,141 \mathrm{X} 1+11,358 \mathrm{X} 2+\mathrm{e}$

1. Nilai konstanta yang diperoleh dari persamaan model regresi penelitian sebesar -11,947.

2. Nilai koefisien variabel Kesulitan Keuangan (X1) yang diperoleh dari persamaan model regresi penelitian sebesar -1,141.

3. Nilai koefisien variabel Tingkat Hutang (X2) yang diperoleh dari persamaan model regresi penelitian sebesar 11,358.

\section{Uji t (Uji Parsial)}

Tabel 5. Uji t

\begin{tabular}{|l|l|l|}
\hline \multicolumn{1}{|c|}{ Variabel } & t Hitung & Sig t \\
\hline $\begin{array}{l}\text { Kesulitan } \\
\text { Keuangan }\end{array}$ & 8,198 & 0,000 \\
\hline $\begin{array}{l}\text { Tingkat } \\
\text { Hutang }\end{array}$ & 7,957 & 0,000 \\
\hline
\end{tabular}

(Sumber : Data diolah, 2021)

1. Variabel Kesulitan Keuangan menghasilkan nilai sig sebesar 0,000

$<$ taraf 0,05 dan t hitung sebesar8,198 > t tabel 2,032. Sehingga disini H0 ditolak $\mathrm{Ha}$ diterima.

2. Variabel Tingkat Hutangmenghasilkan nilai sig sebesar 0,000 
$<\operatorname{taraf} 0,05$ dan $\mathrm{t}$ hitung sebesar7,957 > t tabel 2,032. Sehingga disini $\mathrm{H} 0$ ditolak $\mathrm{H}_{\mathrm{a}}$ diterima.

\section{Uji F (Uji Simultan)}

Tabel 6. Uji F
\begin{tabular}{|l|c|c|}
\hline \multicolumn{1}{|c|}{ Variabel } & F Hitung & Sig F \\
\hline $\begin{array}{l}\text { Kesulitan } \\
\text { Keuangan }\end{array}$ & & \\
\cline { 1 - 1 } $\begin{array}{l}\text { Tingkat } \\
\text { Hutang }\end{array}$ & 44,709 & 0,000 \\
\hline
\end{tabular}

(Sumber : Data diolah, 2021)

Variabel Kesulitan Keuangan dan Tingkat Hutang menghasilkan nilai sig F sebesar $0,000<\operatorname{taraf} 0,05$ dan F hitung sebesar 44,709 > F tabel 3,28. Sehingga disini $\mathrm{H} 0$ ditolak $\mathrm{Ha}$ diterima.

\section{Uji Koefisien Determinasi $\left(\mathbf{R}^{2}\right)$}

\begin{tabular}{|l|l|}
\hline Korelasi $(\mathrm{R})$ & 0,855 \\
\hline Koefisien Determinan $\left(\mathrm{R}_{2}\right)$ & 0,730 \\
\hline
\end{tabular}

(Sumber : Data diolah, 2021)

1. Nilai R sebesar 0,855 artinya adalahkoefisien korelasi atau hubungan antara variabel bebas terhadapvariabel terikat yaitu sebesar 0,855 .

2. Nilai R Square sebesar 0,730 artinya Konservatisme Akuntansi dapat dijelaskan oleh variabel bebas Kesulitan Keuangan dan Tingkat Hutang melalui model regresi sebesar $73 \%$, sisanya $27 \%$ berasal dari variabel lain diluar dari penelitian.

\section{Hasil Penelitian dan Pembahasan}

\section{Kesulitan Keuangan Terhadap Konservatisme Akuntansi}

Hasil dari uji hipotesis secara parsial dapat diketahui bahwa nilai dari sig t sebesar 0,000 dan nilai dari t hitung sebesar 8,198, serta hasil yang diperoleh dari koefisien regresi linier berganda bernilai negatif. Nilai signifikansi yang dihasilkan lebih kecildari taraf signifikansi 0,05 dan nilai t hitung lebih besar dari t tabel. Maka disini H0 ditolak dan H1 diterima yang artinya bahwa Kesulitan Keuangan berpengaruh negatif dan signifikan terhadap Konservatisme Akuntansi pada Perusahaan Food \& Beverage tahun 2018-2020. Disini koefisien variabel bernilai negatif artinya terjadi hubungan negatif antara Kesulitan Keuangan dan Konservatisme Akuntansi. Maka semakin naik nilai dari Kesulitan Keuangan semakin turun nilai Konservatisme Akuntansi.

\section{Tingkat Hutang Terhadap Konservatif Akuntansi}


Hasil dari uji hipotesis secara parsial dapat diketahui bahwa nilai dari sig $\mathrm{t}$ sebesar 0,000 dan nilai dari t hitung sebesar 7,957, serta hasil yang diperoleh dari koefisien regresi linier berganda bernilai positif. Nilai signifikansi yang dihasilkan lebih kecildari taraf signifikansi 0,05 dan nilai t hitung lebih besar dari t tabel. Maka disini H0 diterima dan H1 ditolak yang artinya bahwa Tingkat Hutang berpengaruh positif dan signifikan terhadap Konservatisme Akuntansi pada Perusahaan Food \& Beverage tahun 2018-2020. Disini koefisien variabel bernilai positif artinya terjadi hubungan positif antara Tingkat Hutangdan Konservatisme Akuntansi. Makasemakin naik nilai dari Tingkat Hutangsemakin naik juga nilai Konservatisme Akuntansi.

\section{Kesulitan Keuangan dan Tingkat Hutang Terhadap Konservatif Akuntansi}

Hasil dari uji hipotesis secara simultan dapat diketahui bahwa nilaidari sig F sebesar 0,000 dan nilai dari $\mathrm{F}$ hitung sebesar 44,709. Nilai signifikansi yang dihasilkan lebih kecildari taraf signifikansi 0,05 dan nilai $\mathrm{F}$ hitung lebih besar dari F tabel. Maka disini H0 diterima dan H1 ditolak yang artinya bahwa Kesulitan Keuangan dan Tingkat Hutang berpengaruh signifikan terhadap Konservatisme Akuntansi pada Perusahaan Food \& Beverage tahun 2018-2020. Dan dari hasil analisis regresi linier yang didapatkan nilai koefisien determinasi $\left(\mathrm{R}^{2}\right)$ sebesar0,730 atau bisa dikatakan variabelKonservatisme Akuntansi dapat dijelaskan sebesar $73 \%$ oleh variable Kesulitan Keuangan dan Tingkat Hutang.

\section{Kesimpulan dan Saran}

\section{Kesimpulan}

1. Tingkat Kesulitan Keuangan memiliki pengaruh negatif dan signifikan terhadap Konservatisme Akuntansi pada Perusahaan Food \& Beverage Tahun 2018-2020.

2. Tingkat Hutang memiliki pengaruh positif dan signifikan terhadap Konservatisme Akuntansi pada Perusahaan Food \& Beverage Tahun 20182020. Tingkat Kesulitan Keuangan dan Tingkat Hutang memiliki pengaruh signifikan terhadap Konservatisme Akuntansi pada Perusahaan Food \& Beverage Tahun 2018-2020.

\section{Saran}

\section{Bagi Perusahaan}

Pihak manajemen perusahaan hendaknya mengenali sejak dini kondisi keuangan perusahaan yang terjadi, sehingga bila terjadi masalah yang serius dapat dilakukan upaya penyelamatan sejak awal. Karena berdasarkan hasil penelitian yang telah dilakukan, Tingkat Kesulitan Keuangan dan Tingkat Hutang memiliki pengaruh signifikan terhadap Konservatisme Akuntansi perusahaan. Oleh karena itu, sebaiknya perusahaan berhati-hati ketika mengalami kesulitan keuangan atau memiliki tingkat hutang yang tinggi, 
karena hal ini akan memberikantekanan kepada manajemen dalam perusahaan. Atas tekanan tersebut dapat menimbulkan pelaporan keuangan yang overstatement, pelaporan yang overstatement menandakan pelaporan tersebut tidak konservatif. Dan disini perusahaan harus memberikan laporan keuangan yang berkualitas kepada pihak stakeholder, tidak menerapkan prinsip konservatisme terlaluberlebihan dan hanya menerapkan prinsip tersebut hanya pada saat-saatyang diperlukan.

\section{Bagi Investor}

Bagi investor dan calon investor diharapkan lebih berhati-hati dalam mendapatkan informasi mengenai laporan keuangan perusahaan, dan hasil penelitian ini dapat digunakan pihakinvestor dalam melakukan pengambilan keputusan karena meskipun konsep konservatisme dapat memberikan manfaat namun pengimplementasian konsep konservatisme yang berlebihan juga tidak baik.

\section{Daftar Pustaka}

Alhayati, Fajri. (2013). Pengaruh Tingkat Hutang (Leverage) dan Tingkat Kesulitan Keuangan Perusahaan Terhadap Konservatisme Akuntansi. Skripsi.Dipublikasikan.Padang: Universitas Negeri Padang.

Ghozali. (2016). Aplikasi Analisis Multivariete Dengan Program IBM SPSS. Semarang: BadanPenerbit Universitas Diponegoro.

Hanafi, Mamduh M dan Abdul Halim. (2016). Analisis Laporan Keuangan (edisi 5).Yogyakarta: UPP STIM YKPN

Hantono. (2018). Konsep Analisa Laporan Keuangan dengan Pendekatan Rasio dan SPSS. Sleman: Penerbit CV Budi Utama.

Munawir, S. (2010). Analisis laporan Keuangan Edisi keempat. Cetakan Kelima Belas.Yogyakarta: Liberty

Putri, Merdianeu Utami. (2018). Pengaruh Tingkat Kesulitan Keuangan Perusahaan dan Risiko Litigasi Terhadap Konservatisme Akuntansi pada Perusahaan

Manufaktur. Skripsi. Dipublikasikan. Yogyakarta: Universitas Negeri Yogyakarta.

Ramadhani, Bella Nurlintang dan Dra. Murni Sulistyowati. (2019). Pengaruh Financial Distress,Leverage, Ukuran Perusahaan Terhadap Konservatisme Akuntansi pada Perusahaan Food And Beverage. Advance : Jurnal Akuntansi. Vol 6. No 1. Juli 2019. Hlm. 78-94.

Setyaningsih, Hesty. (2008). Pengaruh Tingkat Kesulitan Keuangan Perusahaan 
Jurnal Cendekia Akuntansi Vol. 2 NNo.2

Terhadap Konservatisme Akuntansi. Jurnal Akuntansi dan Investasi. Vol. 9. No. 1. Januari 2008. Hlm. 91-107.

Sugiyono. (2013). Metode PenelitianKombinasi (Mix Methods). Bandung: Alfabeta. Sachari.

Sujarweni, Wiratna. (2015). Metodologi Penelitian, (jilid 1). Yogyakarta: PUSTAKABARUPRESS

Wijoyo, Nugroho Agung. (2016). Menakar Kinerja Perusahaan Pembiayaan (jilid II). Jakarta: Universitas Indonesia (UI-Press) 